University of Nebraska - Lincoln

DigitalCommons@University of Nebraska - Lincoln

USDA Wildlife Services - Staff Publications

U.S. Department of Agriculture: Animal and Plant Health Inspection Service

$1-1-2021$

\title{
Space use in free-ranging canids: Are gonadal hormones required for territory maintenance?
}

\author{
Eric M. Gese \\ USDA National Wildlife Research Center, Logan, UT, eric.gese@usu.edu \\ Patricia A. Terletzky \\ Utah State University
}

Follow this and additional works at: https://digitalcommons.unl.edu/icwdm_usdanwrc

Part of the Natural Resources and Conservation Commons, Natural Resources Management and Policy Commons, Other Environmental Sciences Commons, Other Veterinary Medicine Commons, Population Biology Commons, Terrestrial and Aquatic Ecology Commons, Veterinary Infectious Diseases Commons, Veterinary Microbiology and Immunobiology Commons, Veterinary Preventive Medicine, Epidemiology, and Public Health Commons, and the Zoology Commons

Gese, Eric M. and Terletzky, Patricia A., "Space use in free-ranging canids: Are gonadal hormones required for territory maintenance?" (2021). USDA Wildlife Services - Staff Publications. 2501.

https://digitalcommons.unl.edu/icwdm_usdanwrc/2501

This Article is brought to you for free and open access by the U.S. Department of Agriculture: Animal and Plant Health Inspection Service at DigitalCommons@University of Nebraska - Lincoln. It has been accepted for inclusion in USDA Wildlife Services - Staff Publications by an authorized administrator of DigitalCommons@University of Nebraska - Lincoln. 


\title{
Space use in free-ranging canids: are gonadal hormones required for territory maintenance?
}

\author{
Eric M. Gese and Patricia A. Terletzky
}

\begin{abstract}
Fertility control among carnivores has been used to reduce depredations on livestock and wild neonates, population control, modify behavior, inhibit genetic introgression, and reduce human-wildlife conflicts. Although there is considerable knowledge on techniques to sterilize carnivores, there is little information concerning how the absence of gonadal hormones influences behavior, space use, and survival of wild canids. We examined territorial fidelity, home-range size and overlap, and survival of 179 surgically sterilized free-ranging canids (124 coyotes (Canis latrans Say, 1823), 55 coyote - red wolf (Canis rufus Audubon and Bachman, 1851) hybrids) with gonadal hormones present (tubal-ligated females $(n=70)$, vasectomized males $(n=73)$ ) versus absent (spayed females $(n=22)$, neutered males $(n=14))$. The absence of gonadal hormones did not influence annual home-range size and home-range overlap, territory fidelity, and annual survival rates. Additionally, no differences were detected across sexes and hormonal treatments in annual home-range size, percent home-range overlap, annual home-range residency rates, and annual survival rates. Methods of fertility control that do not keep gonadal organs intact may prove useful for management without concern for changes in behavior, mainly territoriality, space use, and survival.
\end{abstract}

Key words: coyote, Canis latrans, red wolf, Canis rufus, gonadal hormones, home-range size, hybrid, overlap, sterilization, survival, territory maintenance.

Résumé : La régulation de la fertilité chez les carnivores a été utilisée pour réduire la déprédation du bétail et des nouveaunés d'espèces sauvages, réguler des populations, modifier des comportements, prévenir l’introgression génétique et réduire les conflits entre animaux sauvages et humains. Si les connaissances sur les méthodes de stérilisation des carnivores sont considérables, celles sur l'influence de l'absence d'hormones sexuelles sur le comportement, l'utilisation de l'espace et la survie des canidés sauvages sont très limitées. Nous avons comparé la fidélité territoriale, la taille et le chevauchement des domaines vitaux et la survie de 179 canidés (124 coyotes (Canis latrans Say, 1823), 55 hybrides coyote - loup roux (Canis rufus Audubon et Bachman, 1851)) en liberté stérilisés de manière chirurgicale présentant des hormones sexuelles (femelles aux trompes ligaturées $(n=70)$, mâles vasectomisés $(n=73)$ ) ou non (femelles châtrées $(n=22)$, mâles castrés $(n=14))$. L'absence d'hormones sexuelles n'a pas eu d'influence sur la taille du domaine vital annuel et sur le chevauchement des domaines vitaux, la fidélité au territoire et les taux de survie annuelle. En outre, aucune différence n'a été relevée entre les sexes et les différents traitements hormonaux en ce qui concerne la taille du domaine vital annuelle, le pourcentage de chevauchement des domaines vitaux, la fréquence de résidence dans les domaines vitaux et les taux de survie annuelle. Les méthodes de régulation de la fertilité qui ne maintiennent pas intacts les organes sexuels pourraient s'avérer utiles pour la gestion sans entraîner de répercussions sur les comportements, en particulier la territorialité, l'utilisation de l'espace et la survie. [Traduit par la Rédaction]

Mots-clés : coyote, Canis latrans, loup roux, Canis rufus, hormones sexuelles, taille du domaine vital, hybride, chevauchement, stérilisation, survie, maintien du territoire.

\section{Introduction}

Fertility control of wild carnivores has been proposed as a management tool for many decades (Balser 1964). Fertility control among wild carnivores may be used to reduce depredations on domestic livestock (Bromley and Gese 2001a) and wild neonates (Seidler et al. 2014), as a method of population control (Bailey 1992; Caughley et al. 1992; Mech et al. 1996), to modify behavior (Neville and Remfry 1984), to inhibit genetic introgression (Gese et al. 2015; Gese and Terletzky 2015), and more recently, to reduce human-wildlife conflicts (Massei and Cowan 2014). Fertility control is usually accomplished via surgical or chemical sterilization, endocrine perturbation, and immunocontraception (DeLiberto et al. 1998; Asa 2005; Asa and Moresco 2019). Although there is considerable knowledge concerning the specific techniques used to sterilize carnivores (Asa 2005; Asa and Moresco 2019), there is a paucity of information concerning how the presence or absence of gonadal hormones influences home-range size and fidelity, space use, or the social consequences of fertility control among wild carnivores (Bromley and Gese 2001b; Seidler and Gese 2012). Bromley and Gese (2001b) and Seidler and Gese (2012) both used tubal ligations on female coyotes (Canis latrans Say, 1823) and vasectomies on male coyotes to maintain gonadal hormones, as opposed to spaying

Received 21 April 2021. Accepted 15 July 2021.

E.M. Gese. U.S. Department of Agriculture, Wildlife Services, National Wildlife Research Center, Department of Wildland Resources, Utah State University, Logan, UT 84322, USA.

P.A. Terletzky. Department of Wildland Resources, Utah State University, Logan, UT 84322, USA.

Corresponding author: Eric M. Gese (email: eric.gese@usu.edu).

๑ 2021 The Author(s). Permission for reuse (free in most cases) can be obtained from copyright.com. 
females and neutering males over concern that removing gonadal hormones would cause abandonment of their territories and breaking of pair bonds within the mated pair.

Coyotes are social carnivores that generally occur in packs consisting of an alpha pair, as the primary breeders, and beta individuals that frequently assist in pup rearing and food provisioning (Bekoff and Gese 2003). Both the alpha female and the alpha male participate in territorial maintenance and boundary defense through indirect (e.g., scent marking; Gese and Ruff 1997) and direct (e.g., physical confrontations; Gese 2001) methods. The factors determining whether an animal attains alpha or beta status are complex and are not completely understood. One theory is that gonadal hormones (estrogen and progesterone in females, testosterone in males) are required to achieve and maintain the social rank of alpha animal (Asa et al.1990; Asa 2005). Other factors that could potentially influence social status are physical size and age. Hormonally, it is a paradox: do alpha coyotes achieve alpha status because of elevated hormones, or are hormone levels elevated because an individual is an alpha? Given the lack of information, there is the concern that sterilizing alpha coyotes could have unanticipated consequences such as a breakdown in social structure and changes in territory vigilance (Asa 1995; Jolly et al. 1996; Asa et al. 2005; Asa and Moresco 2019). Linking hormonal changes with alteration of social status can be examined in captivity, but captive studies generally do not allow for the development of territories and home ranges, dispersal events, or abandonment of a nonreproductive mate.

Hormones can influence multiple behaviors in canids including social status, regulation of aggression and the subsequent degree of territorial defense, scent-marking, and mating and courtship (Asa et al. 1990; Asa 2005). Compared with non-breeding subordinate individuals, dominant males have higher levels of testosterone and dominant females generally have higher levels of estrogen and progesterone (Creel et al. 1997; Boonstra et al. 2018; Montgomery et al. 2018), which could possibly induce greater territorial vigilance observed among alpha coyotes (Gese 2001). Although not demonstrated in coyotes, the influence of gonadal hormones (i.e., testosterone, estrogen, and progesterone) on behavior has been demonstrated in other species. Among African wild dogs (Lycaon pictus (Temminck, 1820)), dominant females have higher estrogen and progesterone than subordinates (Creel et al. 1997), and lower estrogen among subordinates may make them less attractive to males and less likely to mate (Creel and Macdonald 1995). Elevated testosterone among dominant males was associated with increased aggression and increased mating success in African wild dogs (Creel et al. 1997). Kennelly and Converse (1993) indicated the loss of gonadal hormones changed male beaver (Castor canadensis Kuhl, 1820) behavior, but sterilization with gonadal hormones still present did not. A captive study of wild-caught brushtail possums (Trichosurus vulpecula (Kerr, 1792)) indicated that testosterone was necessary for establishing social hierarchy during the breeding season, but not during the non-breeding season (Wehi et al. 2006). Territorial male American martens (Martes americana (Turton, 1806)) had higher testosterone levels than transients (Boonstra et al. 2018).

Home-range establishment and maintenance (i.e., fidelity) has also been linked with hormone levels, although there is considerable variability. The percentage of female ricefield rats (Rattus argentiventer (Robinson and Kloss, 1916)) changing their burrows was higher for hormonally sterilized rats than for surgically sterilized and control rats (Jacob and Matulessy 2004). Removal of gonadal hormones in male brushtail possums resulted in a reduction of home-range size, but did not affect home-range size in females (Ramsey 2007).

Studying the effects of sterilization on canids when gonadal hormones are present or not is challenging in free-ranging populations due to the need of capturing individuals and effectively monitoring them after sterilization. Most research on canid sterilization assumed gonadal hormones were necessary for maintenance
Fig. 1. The five county Red Wolf Recovery Experimental Population Area in northeastern North Carolina, USA, including the location of the two largest National Wildlife Refuges (NWR). Base map image from the North Carolina Geodetic Survey; map projection is WGS 1984, UTM Zone $18 \mathrm{~N}$.

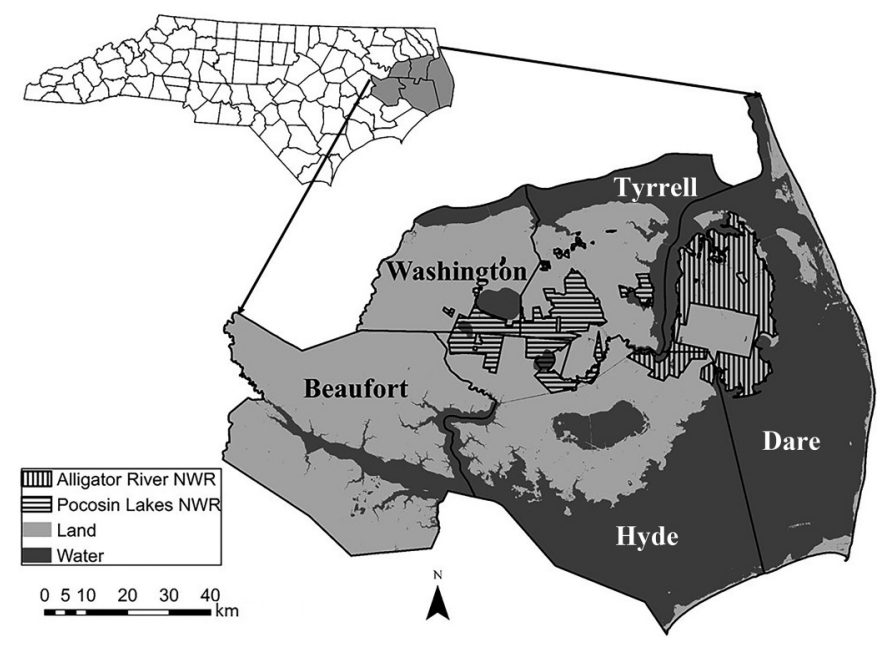

of territories or social status (Asa 2005). Five adult male wolves (Canis lupus Linnaeus, 1758) in Minnesota, USA (Mech et al. 1996), and six adult males in Yukon, Canada (Spence et al. 1999), were vasectomized without changes to territoriality, social status, or pair bonds. Similarly, surgically sterilized (tubal-ligated or vasectomized) coyotes in Utah, USA (Bromley and Gese 2001b), and Colorado, USA (Seidler and Gese 2012), did not exhibit different territory or pack sizes than coyotes that underwent a sham surgery. In New South Wales, Australia, tubal-ligated female European red foxes (Vulpes vulpes (Linnaeus, 1758)) had similar territory sizes to sham vixens, although the sterilized vixens exhibited higher territorial overlap than non-sterilized vixens (Saunders et al. 2002). Although sterilization in canids has shown no impact on their social structure and territoriality, the effects of gonadal hormone removal is unknown. Thus, our objective was to examine home-range size, home-range overlap, territorial fidelity (residency), and survival rates of surgically sterilized free-ranging canids with gonadal hormones present (females were tubal-ligated; males were vasectomized) versus gonadal hormones absent (females were spayed; males were neutered) to test the hypothesis that gonadal hormones are required for territorial maintenance.

\section{Materials and methods}

\section{Study area}

The sterilized animals were part of the Red Wolf Recovery Program located in the Red Wolf Recovery Experimental Population Area (RWREPA) study area in northeastern North Carolina, USA, on the Albemarle Peninsula and encompassed approximately $4900 \mathrm{~km}^{2}$ (Fig. 1). The peninsula is part of the South Atlantic Coastal Plain and is a combination of tidal (estuarine) and non-tidal (palustrine) wetlands, and mixed upland forests. The western region is dominated by mixed pine-hardwood forests of loblolly pine (Pinus taeda L.), white oak (Quercus alba L.), mockernut hickory (Carya tomentosa (Lam. ex Poir.) Nutt.), American beech (Fagus grandifolia Ehrh.), tuliptree (Liriodendron tulipifera L.), sweetgum (Liquidambar styraciflua L.), and red maple (Acer rubrum L.) (Hartshorn 1972).

Pocosins are palustrine wetlands endemic to the Atlantic coast and are found throughout the study area. The acidic and nutrientpoor soils of pocosins facilitate dominance by pond pine (Pinus serotina Michx.), although loblolly pine and longleaf pine (Pinus 
palustris Mill.) are common. The vegetation of the central region exhibits a gradual west-to-east change from upland species to palustrine wetlands dominated by black tupelo (Nyssa sylvatica Marshall), Atlantic white cedar (Chamaecyparis thyoides (L.) Britton, Sterns and Poggenb.), loblolly pine, and bald cypress (Taxodium distichum (L.) Rich.) (Lynch and Peacock 1982; Moorhead and Brinson 1995). Estuarine wetlands have their highest incidence in the eastern region of the study area (mainly Dare and Hyde counties), primarily along the coastline and are dominated by black rush (Juncus roemerianus Scheele) with areas of wetland grasses (smooth cordgrass (Spartina alterniflora Loisel.), saltmeadow cordgrass (Spartina patens (Aiton) Muhl.), Jamaica swamp sawgrass (Cladium jamaicense Crantz)), marsh elder (Iva frutescens L.), and saltwater false willow (Baccharis angustifolia Michx.) (Moorhead 1992).

Within the RWREPA, the principal landowners were private timber and agricultural corporations with federal and state governments having the next highest proportion of ownership. There were numerous wildlife refuges contained within the study area with the two largest being the Alligator River National Wildlife Refuge (ARNWR) and Pocosin Lakes National Wildlife Refuge (PLNWR). The ARNWR is located in the extreme northeastern section of the study area and was designated as the initial red wolf reintroduction site in 1987 due to a lack of coyotes and human presence, but with abundant prey (Phillips and Parker 1988). Mean annual rainfall for ARNWR was $145 \mathrm{~cm}$ without seasonal fluctuations, although $4.8 \mathrm{~cm}$ of snow falls annually during the winter (U.S. Department of the Interior 2008). The 44560 ha PLNWR is located in the central portion of the study area. The total human population for the study area in 2010 was 105124 people (U.S. Census Bureau 2010).

\section{Capture, sterilization, and monitoring}

Coyotes and hybrids (coyote $\times$ red wolf) were captured in conjunction with red wolves (Canis rufus Audubon and Bachman, 1851) to determine the spatial extent and amount of coyote genetic introgression in red wolves (Stoskopf et al. 2005; Gese et al. 2015). Coyotes and hybrids were sterilized to determine the effectiveness of the placeholder concept on reducing hybridization between coyotes and red wolves (Gese and Terletzky 2015). All capture, handling, aerial telemetry, and monitoring of coyotes and hybrids was conducted by United States Fish and Wildlife Service (USFWS) personnel under permits and standard operating protocols approved by the USFWS. As described in Hinton et al. (2015), coyotes and hybrids were captured in padded, foot-hold traps (Victor \#3 Softcatch; Woodstream Corporation, Lititz, Pennsylvania, USA) and transported to a surgical facility, surgically sterilized by a veterinarian, body measurements and mass recorded, blood drawn, aged by tooth wear, and fitted with a VHF radio collar (Telonics, Mesa, Arizona, USA). Age classes included adult ( $<2$ years old), juvenile (1-2 years old), and pup ( $<1$ year old). Females were either tubal-ligated (gonadal hormones present) or spayed (gonadal hormones absent), and males were vasectomized (gonadal hormones present) or neutered (gonadal hormones absent). All surgical procedures were conducted by a licensed veterinarian after the animals were anesthetized. Animals were monitored overnight for post-operative complications and released at the capture site the following day. All captured coyotes and hybrids were either sterilized or removed (euthanized), thus non-sterilized coyotes and hybrids were not available for monitoring in the study area (Kelly 2000; Gese et al. 2015). Animals were genetically tested to determine if they were coyotes, red wolves, or hybrids (Miller et al. 2003; Adams 2006; Bohling et al. 2013).

\section{Spatial analysis}

Radio-collared coyotes and hybrids were located 2-3 times/ week using aerial and ground telemetry to identify territories (Gese and Terletzky 2015; Hinton et al. 2015; U.S. Fish and Wildlife Service 2018). Ground and aerial tracking produced, on average,
Fig. 2. Home ranges of sterilized coyotes (Canis latrans) and coyote - red wolf (Canis rufus) hybrids in the Red Wolf Recovery Experimental Population Area, North Carolina, USA, 1999-2013. Base map image from the North Carolina Geodetic Survey; map projection is WGS 1984, UTM Zone $18 \mathrm{~N}$.

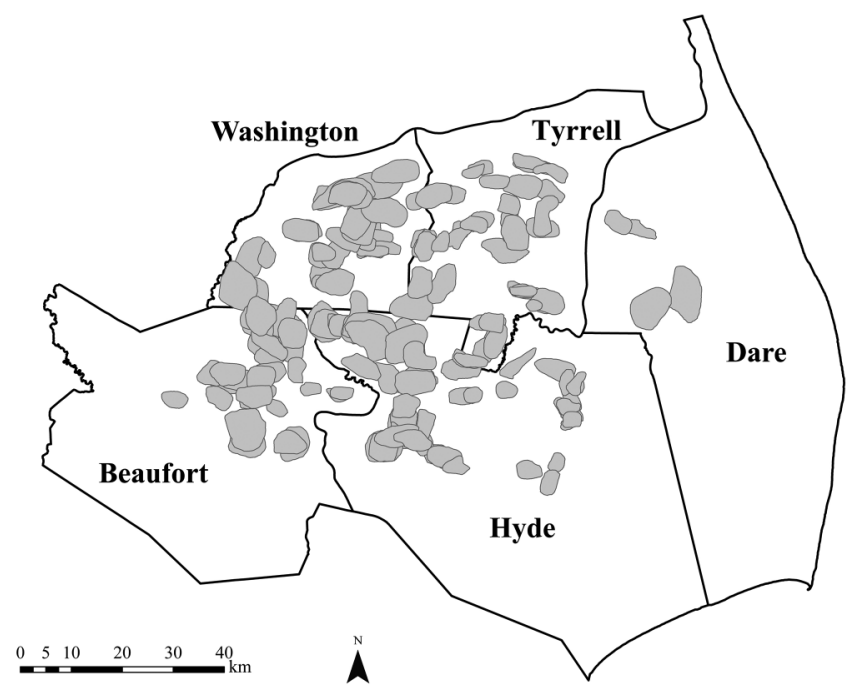

about 100 locations per animal per year, and were used to estimate 95\% fixed kernel home ranges (Worton 1989) for each animal with adequate location sample size. Construction of area-observation curves (Odum and Kuenzler 1955; Fuller and Snow 1988) showed that a minimum of 35 locations were needed to estimate a home range, similar to home ranges of coyotes in Colorado (Gese et al. 1990). Animals without this minimum were excluded from analyses of home-range size and percent home-range overlap $(n=11)$. Changes in home-range boundaries were noted as were any radiocollared coyotes or hybrids present within a home range. If homerange boundaries for an animal changed over time, then these new boundaries were incorporated into the spatial analyses (i.e., any changes in a home range were also changed on a temporal scale to match any new overlap with adjacent animals). Sterilized animals were monitored as long as they were alive or remained in the study area. The shortest monitoring period for a sterilized animal was 1 month and the longest was 12.2 years.

We examined the amount of overlap for home ranges by considering both temporal and spatial overlap. Temporal overlap occurred when radio-collared animals established home ranges on the study area during the same months and years. To avoid incorrectly assigning a transient to a home range, temporal overlaps $\leq 3$ months were not included in the analysis. Spatial overlap occurred when neighboring or adjacent home ranges overlapped in physical and temporal space. We defined neighboring home ranges as those whose boundaries were $\leq 1.33 \mathrm{~km}$ away (i.e., the radius of the smallest home range) from the edge of the focal home range, and was the minimum distance used to exclude the potential presence of a home range in which the pack members were not radio-collared (Seidler and Gese 2012). Overlap was determined by examining only those home ranges that exhibited simultaneous temporal and spatial overlap.

We also determined the annual rate of territory fidelity or residency based on the number of radio-days and number of dispersals that occurred for the radio-collared animals within each treatment type for each year; similar to estimating survival rates but using dispersals as deaths. We used only known dispersal events because a lost signal $(n=34)$ from an animal could have been a radio-collar failure or a dispersal outside the recovery or tracking area. Lost signals of animals were assumed to be collar 
Fig. 3. Mean $( \pm S D)$ home-range size of female canids with gonadal hormones absent (spay, $n=19)$ and gonadal hormones present (tubal ligation, $n=64$ ), and male canids with gonadal hormones absent (neuter, $n=12$ ) and gonadal hormones present (vasectomy, $n=73$ ), in northeastern North Carolina, USA, 1999-2013.

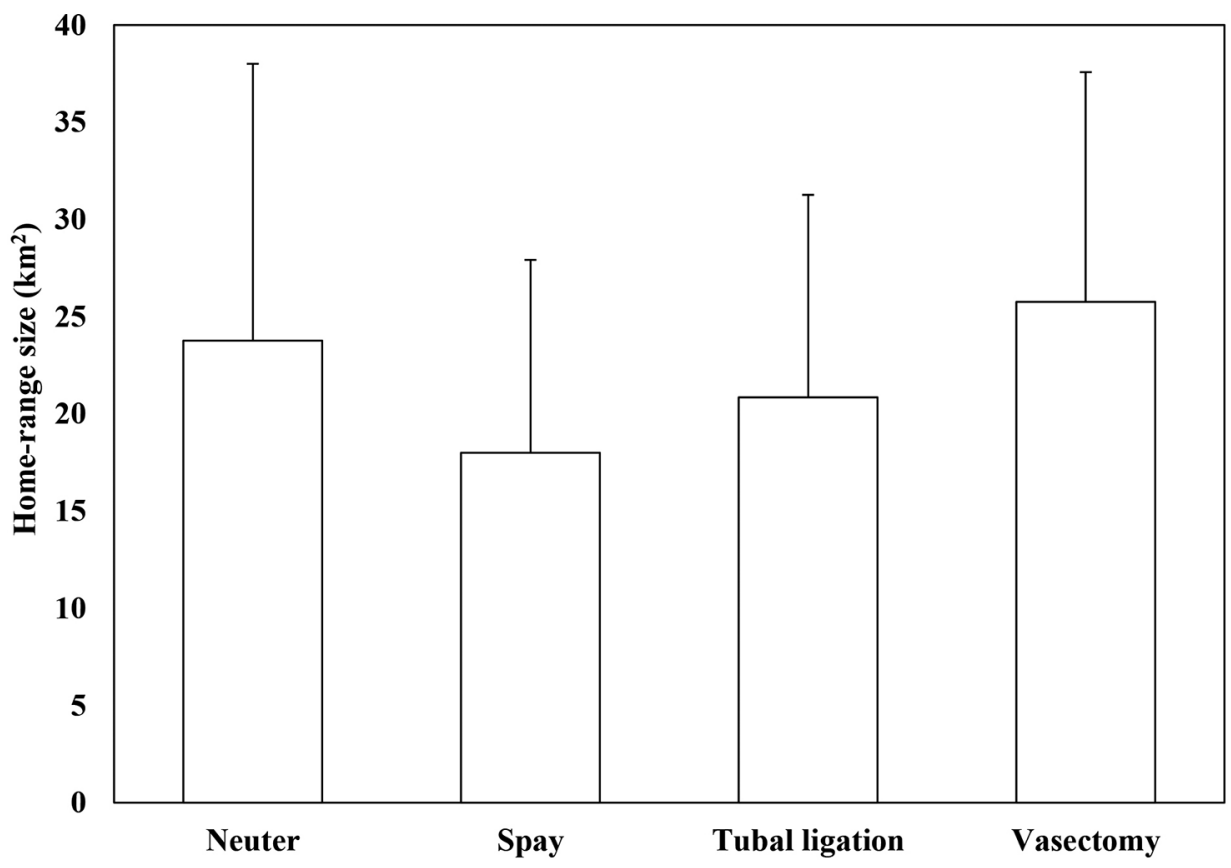

failures rather than dispersal events and were omitted from analyses. Dispersal was defined as either natal dispersal (i.e., movement from the natal pack) or breeding dispersal (i.e., movement by an adult out of its current home range) (Gese and Mech 1991; Boyd and Pletscher 1999; Karlin and Chadwick 2012). We calculated the mean annual home-range fidelity rates from 1999 to 2013 for females with gonadal hormones present and males with gonadal hormones present. Spaying (gonadal hormones absent) occurred from 2007 to 2013, so mean values for spayed females were calculated only during those years. Neutering (gonadal hormones absent) occurred from 2006 to 2013, so mean values for neutered males were calculated only during those years.

The focus of our research was on the gonadal hormone status of individual coyotes and hybrids; hence, home ranges were assigned to a single individual. Occasionally a single home range was assigned to two animals when both were sterilized and associated with the same home range (i.e., members of the same pack). Although both alpha females and alpha males contribute to territorial defense, alpha males conduct a higher portion of defense than alpha females (Gese 1998, 2001). To avoid pseudoreplication when having two animals occupying the same home range (i.e., members of the same pack and territory), we chose only one individual to represent that home range in our analysis. Thus, when a sterilized male and a sterilized female were associated with the same home range, we assigned the home range to the male and omitted the female from the analysis. In addition, older individuals likely have greater experience defending a territory than younger individuals (Schwartz et al. 2007), thus when two females or two males were associated with the same home range, the older individual was assigned to the home range and the younger one omitted from the analysis. If the two individuals were determined to be litter mates, then we randomly selected one animal to represent the home range and the other removed from analysis. If the age or litter designation was not discernable between the two individuals, then we retained the individual with the greater amount of data (i.e., longer time of monitoring) and the other animal was censured from analysis.

\section{Survival rates}

Radio-collared, sterile coyotes and hybrids found dead were field necropsied or examined by a veterinarian to determine the cause of death (Gese et al. 2015; Gese and Terletzky 2015). Although mortalities were classified into anthropogenic, natural, or unknown, for this research we did not distinguish between causes of death. We calculated annual survival rates for females and males with gonadal hormones present and absent using the program MICROMORT (Heisey and Fuller 1985).

\section{Statistical analysis}

We conducted Student's $t$ tests (Zar 1996) to determine if annual survival rates, home-range size, territory fidelity (residency rates), and proportion of home-range overlap were significantly different between females and males; between all individuals with gonadal hormones present (tubal ligation and vasectomy) and gonadal hormones absent (spay and neuter); and between females (males) with gonadal hormones present and females (males) with gonadal hormones absent. Due to different gonadal hormones, analyzing the sexes separately seemed most appropriate given the physiological differences between the sexes may produce different spatial responses. To examine differences among all treatments (tubal ligation, vasectomy, spay, and neuter), we conducted an analysis of variance (ANOVA), followed by a Tukey's honestly significant difference (Tukey's HSD) test (Zar 1996), to determine which treatments influenced survival and home-range size, territory fidelity, and proportion of overlap. We also examined the focal animal - neighbor relationship (e.g., spay - tubal ligation, spay-spay, spay-vasectomy, spay-neuter) with an ANOVA. All spatial evaluations were conducted in ArcGIS (Environment Systems Research Institute (esri), Inc., Redlands, California, USA) and all statistical analyses were conducted in the R statistical software (R Core Team 2015).

\section{Results}

We examined spatial data and survival rates from 179 sterilized canids (124 coyotes, 55 hybrids; 92 females, 87 males; Fig. 2). Most 
Fig. 4. Mean $( \pm S D)$ annual residency rates of female canids with gonadal hormones absent (spay, $n=20)$ and gonadal hormones present (tubal ligation, $n=70$ ), and male canids with gonadal hormones absent (neuter, $n=14$ ) and gonadal hormones present (vasectomy, $n=73$ ), in northeastern North Carolina, USA, 1999-2013.

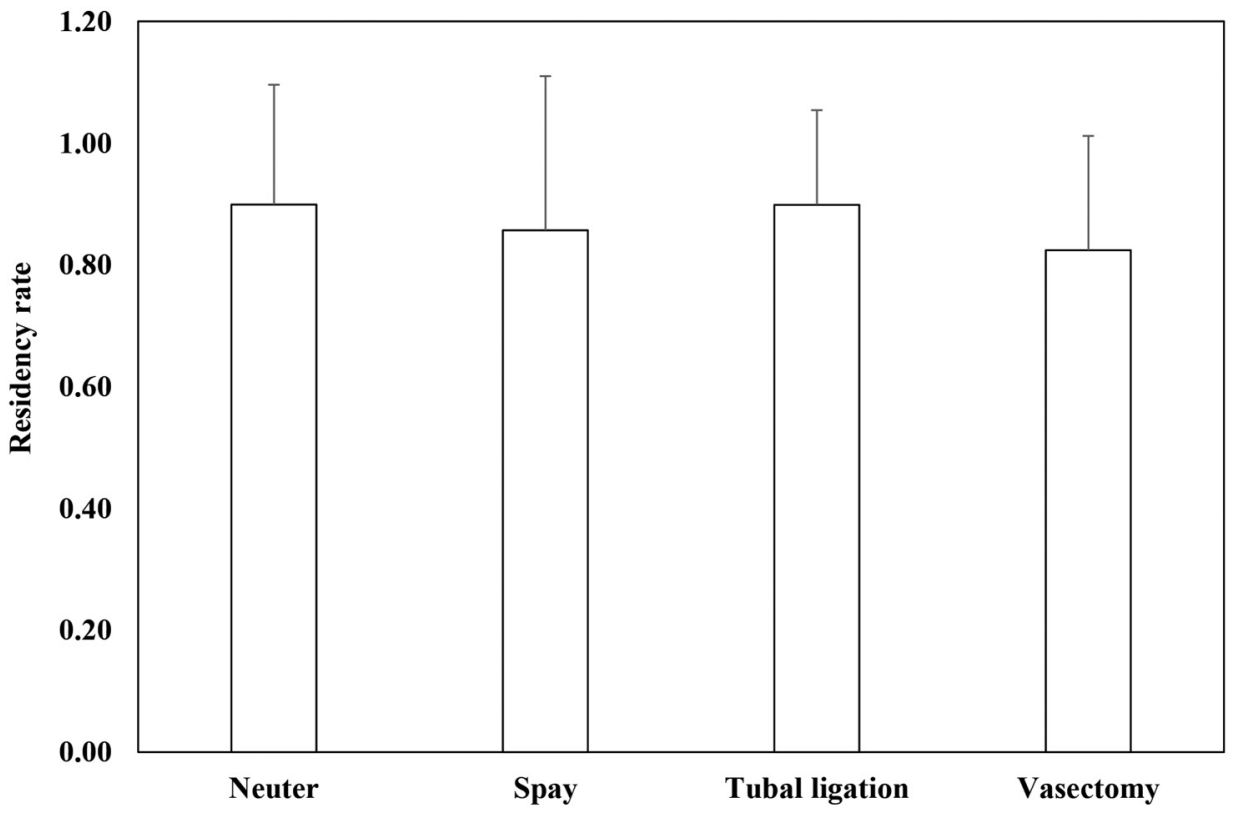

$(n=70)$ females were tubal-ligated (gonadal hormones present), while $23.9 \%(n=22)$ were spayed (gonadal hormones absent). As with the females, most males $(n=73)$ were vasectomized (gonadal hormones present), while $16.1 \%(n=14)$ were neutered (gonadal hormones absent). Construction of area-observation curves showed 168 animals met the minimum location sample size required for estimating a home range. Across sexes and hormonal treatment, the mean ( $\pm \mathrm{SD}$ ) home-range size was $23 \pm 11.5 \mathrm{~km}^{2}$. The largest home range was associated with a male with gonadal hormones present $\left(64.5 \mathrm{~km}^{2}\right)$ and the smallest home range was a male with gonadal hormones present $\left(5.5 \mathrm{~km}^{2}\right.$, radius of $\left.1.33 \mathrm{~km}\right)$. The mean $( \pm S D)$ male home range $\left(25.5 \pm 12.1 \mathrm{~km}^{2}\right)$ was significantly $\left(t_{[164]}=-3.06, P=0.003\right)$ larger than the mean $( \pm S D)$ female home range $\left(20.2 \pm 10.3 \mathrm{~km}^{2}\right)$. There was no significant difference $\left(t_{[43]}=-1.39, P=0.17\right)$ between mean home-range size of canids with gonadal hormones present (tubal ligation and vasectomy) and gonadal hormones absent (spay and neuter). While mean $( \pm \mathrm{SD})$ home-range size was generally larger when gonadal hormones were present for females $\left(20.8 \pm 10.4 \mathrm{~km}^{2}, n=64\right)$ than when gonadal hormones were absent $\left(17.9 \pm 9.9 \mathrm{~km}^{2}, n=19\right)$, there was no significant difference $\left(t_{[31]}=1.09, P=0.28\right)$ between the two treatments. As with females, males with gonadal hormones present had slightly larger mean $( \pm \mathrm{SD})$ home ranges $\left(25.8 \pm 11.8 \mathrm{~km}^{2}, n=73\right)$ than males without gonadal hormones $\left(23.8 \pm 14.2 \mathrm{~km}^{2}, n=12\right)$, but was not significantly different $\left(t_{[14]}=0.46, P=0.65\right)$ between the two treatments. An ANOVA indicated there was no treatment effect (tubal ligation, vasectomy, spay, and neuter) on home-range size $\left(F_{[3,41]}=2.02, P=0.16\right.$; Fig. 3$)$.

We used all 179 sterilized animals for determination of homerange fidelity. The mean annual home-range fidelity rates were not significantly different $\left(t_{[43]}=0.62, P=0.54\right)$ between females $(0.89 \pm 0.19)$ and males $(0.85 \pm 0.19)$. There was no significant difference $\left(t_{[9]}=-0.40, P=0.70\right)$ in mean annual home-range fidelity rates between females with gonadal hormones present $(0.90 \pm$ $0.16, n=70)$ and females with gonadal hormones absent $(0.86 \pm$ $0.25, n=20$ ). Of the 15 years examined for females undergoing tubal ligation (gonadal hormones present), 1999 had a mean annual fidelity rate of 0.45 with all other years exhibiting residency rates $\geq 0.71$. Females undergoing spaying exhibited a mean annual
Table 1. The number of overlapping canid home ranges per focal individual for sterilized canids in northeastern North Carolina, USA, 1999-2013.

\begin{tabular}{lcll}
\hline $\begin{array}{l}\text { Number of } \\
\text { overlapping areas }\end{array}$ & $\begin{array}{l}\text { Number of focal } \\
\text { individuals }\end{array}$ & $\begin{array}{l}\text { Number of } \\
\text { females }\end{array}$ & $\begin{array}{l}\text { Number of } \\
\text { males }\end{array}$ \\
\hline 0 & 50 & 25 & 25 \\
1 & 49 & 26 & 23 \\
2 & 25 & 13 & 12 \\
3 & 14 & 5 & 9 \\
4 & 10 & 6 & 4 \\
5 & 6 & 2 & 4 \\
6 & 2 & 0 & 2 \\
7 & 2 & 1 & 1 \\
8 & 1 & 0 & 1 \\
\hline Total & 159 & 78 & 81 \\
\hline
\end{tabular}

home-range fidelity rate of 0.38 in 2008 with the other 6 years having fidelity rates $\geq 0.62$. Males exhibited a similar pattern to the females for mean annual home-range fidelity rates with no significant difference $\left(t_{[14]}=0.89, P=0.39\right)$ between males with gonadal hormones present $(0.82 \pm 0.19, n=73)$ and males with gonadal hormones absent $(0.90 \pm 0.20, n=14)$. Of the 15 years examined for males undergoing vasectomy, only 1999 and 2001 exhibited mean annual fidelity rates of $\leq 0.48$ with all other years exhibiting rates $\geq 0.64$. Males undergoing neutering only exhibited mean annual home-range fidelity rates of $\leq 0.48$ in 2007 with the other 7 years having fidelity rates $\geq 0.72$. An ANOVA indicated there was no treatment effect (tubal ligation, vasectomy, spay, and neuter) on mean annual home-range fidelity rates $\left(F_{[3,41]}=\right.$ $0.79, P=0.50$; Fig. 4 ).

There were 159 home ranges of sterilized canids that were within $1.33 \mathrm{~km}$ of a neighboring home range that exhibited both spatial and temporal home-range overlap. There was an inverse relationship between the number of focal animals exposed to overlapping areas and the number of overlapping areas (Table 1). More males $(n=21)$ exhibited home-range overlap when three or more neighbors were within $1.33 \mathrm{~km}$ of their home-range 
Fig. 5. Mean $( \pm S D)$ proportion of home-range overlap of female canids with gonadal hormones absent (spay, $n=19)$ and gonadal hormones present (tubal ligation, $n=64$ ), and male canids with gonadal hormones absent (neuter, $n=12$ ) and gonadal hormones present (vasectomy, $n=73$ ), in northeastern North Carolina, USA, 1999-2013.

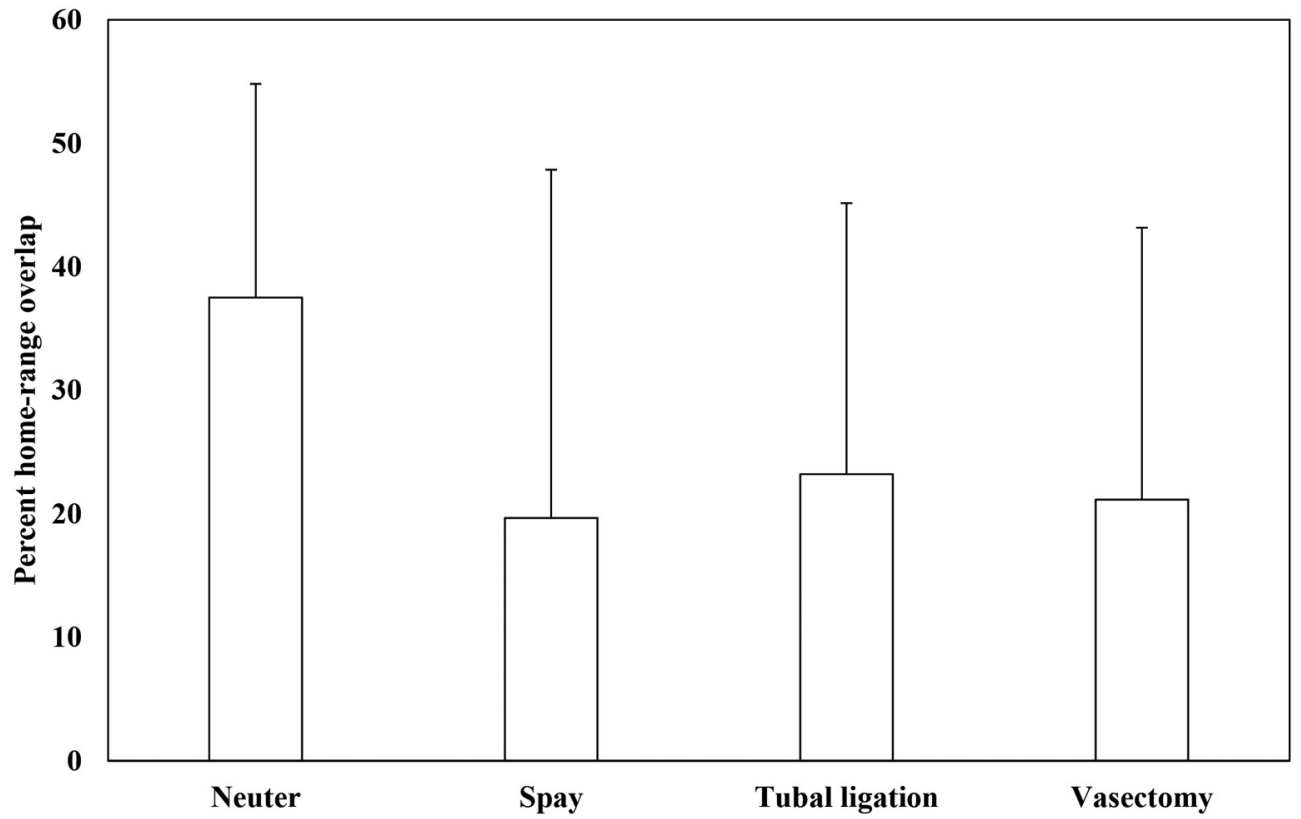

boundary than females ( $n=14$; Table 1$)$. We used the mean area of home-range overlap for a focal canid if there were multiple ranges overlapping with neighboring sterilized canids when we analyzed the proportion of overlap. The mean $( \pm S D)$ proportion of home-range overlap for a focal animal was $0.21 \pm 0.26$ with the largest proportion being 0.95 and the smallest being 0 (i.e., there was a neighboring canid home range within $1.33 \mathrm{~km}$, but it did not overlap with the neighboring canid home range). There were no significant differences $\left(F_{[3,41]}=1.17, P=0.32\right)$ in the proportion of home-range overlap among sterilization methods (i.e., tubal ligation, vasectomy, spay, and neuter), or between sterilization status (i.e., gonadal hormones present, gonadal hormones absent; $F_{[1,41]}=0.41, P=0.52$; Fig. 5). The ANOVA of the relationship between the focal animal and the neighboring animal indicated there was a treatment effect $\left(F_{[1,14]}=1.91, P=0.03\right)$ such that there were significant differences when the focal animal was a male with gonadal hormones present (vasectomy) and the overlapping neighbor was a female with gonadal hormones absent (spay) compared with a female focal animal with gonadal hormones present (tubal ligation) with a male neighbor with gonadal hormones absent (neuter; Table 2).

We estimated annual survival rates for 179 sterilized canids monitored for 135263 radio-days (55622 radio-days for 70 females with gonadal hormones present; 12626 radio-days for 22 females with gonadal hormones absent; 54163 radio-days for 73 males with gonadal hormones present; 12852 radio-days for 14 males with gonadal hormones absent). Annual survival rates were not significantly different $\left(t_{[44]}=0.28, P=0.78\right)$ between females $(0.80 \pm 0.15)$ and males $(0.79 \pm 0.14)$. There was no significant difference $\left(t_{[20]}=-0.07, P=0.94\right)$ in annual survival rates between females with gonadal hormones present $(0.80 \pm 0.15)$ and females with gonadal hormones absent $(0.79 \pm 0.16)$. Males exhibited a similar pattern to the females for annual survival rates with no significant difference $\left(t_{[13]}=1.56, P=0.14\right)$ between males with gonadal hormones present $(0.75 \pm 0.13)$ and males with gonadal hormones absent $(0.85 \pm 0.15)$. An ANOVA indicated there was no treatment effect (tubal ligation, vasectomy, spay, and neuter) on annual survival rates $\left(F_{[3,41]}=0.47, P=0.70\right.$; Fig. 6$)$.
Table 2. Results of a Tukey's honestly signficiant difference test indicating the significant differences between the proportion of home-range overlap between focal and neighboring canids, according to the type of sterilization method, in northeastern North Carolina, USA, 1999-2013.

\begin{tabular}{lll}
\hline Focal-neighbor & Focal-neighbor & $P$ \\
\hline Vasectomy-spay & Tubal ligation - neuter & 0.05 \\
Tubal ligation - neuter & Spay-vasectomy & 0.09 \\
Vasectomy-spay & Neuter - tubal ligation & 0.09 \\
\hline
\end{tabular}

\section{Discussion}

Overall, the absence of gonadal hormones did not influence female or male canid survival rates, home-range size, homerange fidelity, or proportion of home-range overlap with neighboring sterilized canids. We acknowledge that the lower sample sizes of both spayed females and neutered males reduced our power to detect differences between treatments. Prior research has indicated that sterilization of canids, but leaving gonadal hormones present, did not influence home-range size or social status among sterile wolves (Mech et al. 1996), or between sterile and sham-operated (intact) coyotes in Utah (Bromley and Gese 2001b) and Colorado (Seidler and Gese 2012), although the proportion of overlap with neighbors could change with sterilization (Saunders et al. 2002). Although not significant, foxes with gonadal hormones present had larger home ranges than those without gonadal hormones, suggesting that gonadal hormones may facilitate movement across the landscape possibly due to provisioning of pups (Saunders et al. 2002). Gonadal hormones could increase forays beyond the home range, could necessitate increased predation and prey consumption, or require provisioning for pups thus increasing predation on domestic and native ungulates (Bromley and Gese 2001a; Saunders et al. 2002; Seidler et al. 2014).

Annual home-range fidelity rates were similar regardless if gonadal hormones were present or absent, again suggesting that territorial maintenance was not dependent solely on hormones 
Fig. 6. Mean $( \pm S D)$ annual survival rates of female canids with gonadal hormones absent (spay, $n=22$ ) and gonadal hormones present (tubal ligation, $n=70$ ), and male canids with gonadal hormones absent (neuter, $n=14$ ) and gonadal hormones present (vasectomy, $n=73$ ), in northeastern North Carolina, USA, 1999-2013.

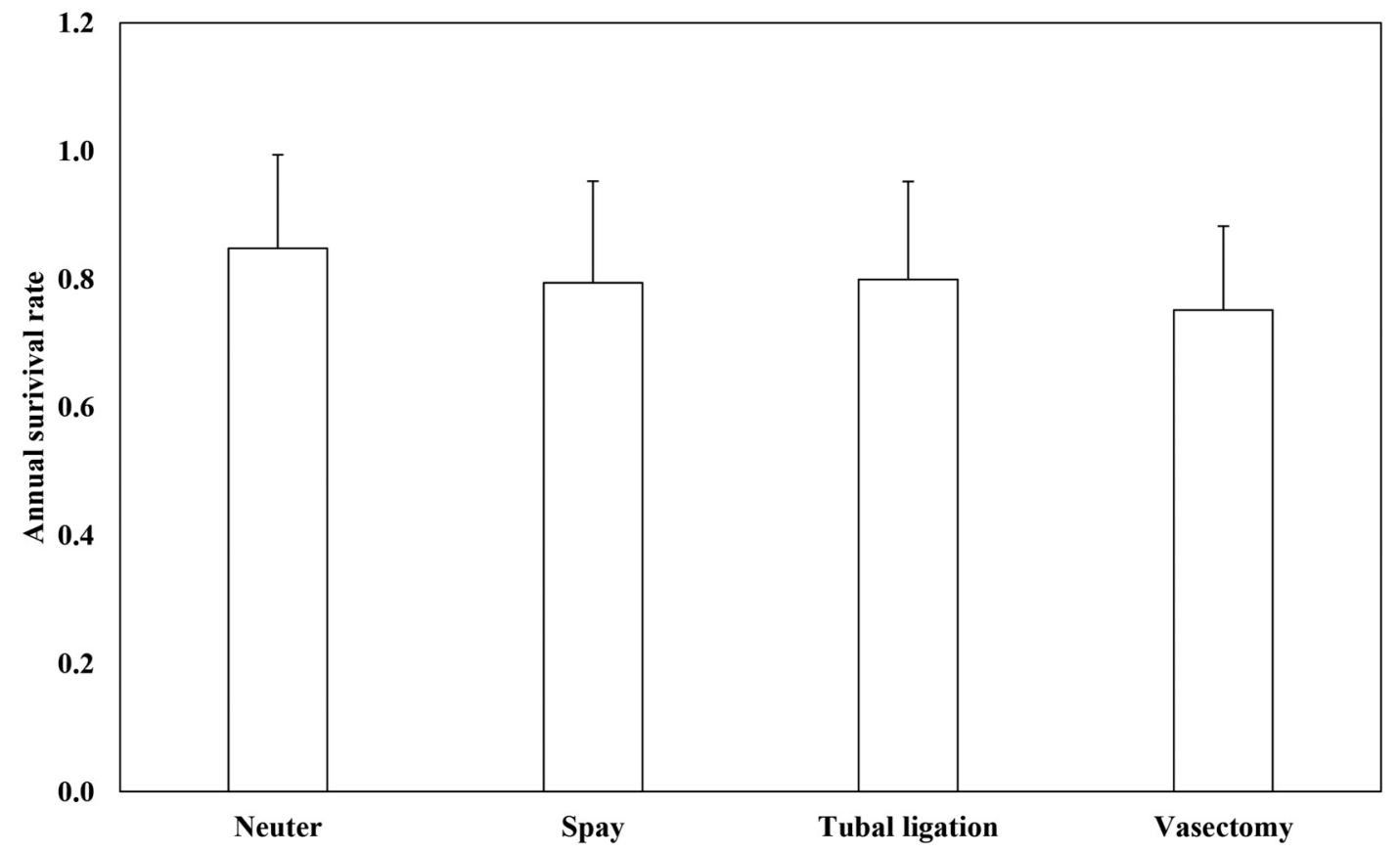

but likely influenced by other factors such as prey density and availability, survival of the alpha partner, and trespass from neighboring canids. Bromley and Gese (2001b) found equally high rates of territory fidelity among sterile coyotes in Utah. Seidler and Gese (2012) also reported no difference in territory fidelity between sterile and intact coyotes in Colorado. Similar to homerange size, home-range fidelity is likely influenced by a combination of non-hormonally based factors such as prey density and availability, or mate survival.

The proportion of overlap with neighboring sterilized canids was not influenced by the presence or absence of gonadal hormones, but most (78\%) focal animals had 0-2 overlapping areas with the remaining $12 \%$ having $>3$ overlapping areas. Spence et al. (1999) reported that all sterilized wolf pairs maintained their pair bonds and territories. Similarly, Bromley and Gese (2001b) found no difference in home-range overlap of sterile and shamoperated (hormonally intact) coyote packs. The propensity to have exclusive home ranges without overlap in conjunction with the high mean annual home-range fidelity suggests that gonadal hormones may not be necessary to maintain home ranges.

The presence or absence of gonadal hormones did not influence annual survival of sterilized canids. Bromley and Gese (2001b) reported higher survival among sterile coyotes versus sham-operated animals in 2 of 3 years of their study in Utah. In Colorado, survival rates were correlated with biological season, but there were no differences in survival rates between sterile and intact coyotes (Seidler and Gese 2012). Although coyotes and hybrids in the study area were sterilized to reduce introgression with red wolves (Gese and Terletzky 2015), over $40 \%$ of canid deaths were human caused (gunshot, hunter killed, or suspected foul play). Sterilized female foxes may live longer than reproductive females due to reduced stress of reproduction (Saunders et al. 2002).

Our results indicate that gonadal hormones are not needed to maintain an established home range and thus may not be an integral aspect of territorial maintenance and defense (Asa 2005). Asa (2005) theorized that territorial defense is manifested by the presence of gonadal hormones and results in increased aggression. Our research suggested that territorial defense, and by extension, home-range fidelity, was not directed solely by gonadal hormones, but potentially by a combination of hormones, response to the presence of pups and pup provisioning, and social interactions among individuals in a pack.

Maintenance of the hierarchical organization of canid packs is essential for successful sterilization programs and to ensure stable territorial placement across the landscape (Caughley et al. 1992; Kennelly and Converse 1993; Spence et al. 1999; Bromley and Gese 2001b). Although there have been few studies examining long-term changes in behavior as a result of sterilization, Mech et al. (1996) found that sterilized vasectomized male wolves in Minnesota maintained territories and pair bonds for more than 7 years. Kennelly and Converse (1993) suggested that sterilization likely does not influence behavior in monogamous species, but sterilization does change behaviors in polygamous species. Our research indicated that gonadal hormones were not necessarily needed to maintain a home range or conduct territorial defense. The role that gonadal hormones plays in the establishment of a home range is uncertain, and because we were unaware of the social status of each sterilized canid at the time of capture, we were not able to address whether gonadal hormones were required for the initial establishment of a home range or the initial attainment of alpha status.

The use of sterilization as a management tool for a canid population has generally been based on the premise that the gonadal hormones must remain intact. Whether using sterilization to control population size (Bailey 1992; Mech et al. 1996), reduce predation rates on livestock (Bromley and Gese 2001a) or wild neonates (Seidler et al. 2014), modify behavior (Neville and Remfry 1984), or manage genetic introgression with sympatric canids (Gese and Terletzky 2015), sterilization has usually been accomplished by tubal ligation of females and vasectomizing of males. Even pursuit of immunocontraception agents has generally been discouraged for fear of disrupting pair bonds and territorial maintenance. Acknowledging the smaller sample sizes of spayed females and neutered males, results from this analysis indicate 
that gonadal hormones may not be necessary to maintain a home range among wild canids. Surgical sterilization involving spaying of females and neutering of males is the more common technique in veterinary clinics and is generally less expensive and time consuming than tubal ligation and vasectomy. Methods of fertility control that eliminate the gonadal hormones may be a viable option as a future management tool.

\section{Competing interests statement}

The findings and conclusions in the article have not been formally disseminated by the U.S. Department of Agriculture and should not be construed to represent any agency determination or policy.

\section{Funding, protocol, and permit information}

Funding, capture protocols, and permitting for all field aspects and data collection were under the auspices of the U.S. Fish and Wildlife Service. Additional support for data analysis and manuscript preparation provided by the U.S. Department of Agriculture, Wildlife Services, National Wildlife Research Center, Logan Field Station, Logan, Utah.

\section{Acknowledgements}

We gratefully acknowledge all of the U.S. Fish and Wildlife Service personnel associated with the red wolf recovery effort for their diligence in documenting their efforts, locating the animals, and providing access to their data, including A. Beyer, B. Fazio, R. Harrison, B. Kelly, C. Lucash, F. Mauney, S. McLellan, M. Morse, L. Schutte, and K. Whidbee. We also thank K. Beck for field assistance.

\section{References}

Adams, J.R. 2006. A multi-faceted molecular approach to red wolf Canis rufus conservation and management. Ph.D. dissertation, University of Idaho, Moscow.

Asa, C.S. 1995. Physiological and social aspects of reproduction of the wolf and their implications for contraception. In Ecology and conservation of wolves in a changing world. Edited by L.N. Carbyn, S.H. Fritts, and D.R. Seip. Occasional Publication Number 35, Canadian Circumpolar Institute, University of Alberta, Edmonton. pp. 283-286.

Asa, C.S. 2005. Types of contraception: the choices. In Wildlife contraception: issues, methods, and applications. Edited by C.S. Asa and I.J. Porton. Johns Hopkins University Press, Baltimore, Md. pp. 29-52. doi:10.2193/ 2007-568.

Asa, C., and Moresco, A. 2019. Fertility control in wildlife: review of current status, including novel and future technologies. In Reproductive sciences in animal conservation. Edited by P. Comizzoli, J. Brown, and W. Holt. Springer Nature, Basingtoke, U.K. pp. 507-543. doi:10.1007/978-3-030-23633-5_17.

Asa, C.S., Mech, L.D., Seal, U.S., and Plotka, E.D. 1990. The influence of social and endocrine factors on urine-marking by captive wolves (Canis lupus). Horm. Behav. 24: 497-509. doi:10.1016/0018-506X(90)90038-Y.

Asa, C.S., Porton, I.J., and Calle, P.P. 2005. Choosing the most appropriate contraceptive. In Wildlife contraception: issues, methods, and applications. Edited by C.S. Asa and I.J. Porton. Johns Hopkins University Press, Baltimore, Md. pp. 83-95. doi:10.2193/2007-568.

Bailey, E.P. 1992. Red foxes (Vulpes vulpes) as biological control agents for introduced arctic foxes (Alopex lagopus) on Alaskan Islands. Can. Field-Nat. 106: 200-205

Balser, D.S. 1964. Management of predator populations with antifertility agents. J. Wildl. Manage. 28: 352-358. doi:10.2307/3798097.

Bekoff, M., and Gese, E.M. 2003. Coyote (Canis latrans). In Wild mammals of North America: biology, management, and conservation. 2nd ed. Edited by G.A. Feldhamer, B.C. Thompson, and J.A. Chapman. Johns Hopkins University Press, Baltimore, Md. pp. 467-481.

Bohling, J.H., Adams, J.R., and Waits, L.P. 2013. Evaluating the ability of Bayesian clustering methods to detect hybridization and introgression using an empirical red wolf data set. Mol. Ecol. 22: 74-86. doi:10.1111/ mec.12109.

Boonstra, R., Dušek, A., and Flynn, R.W. 2018. DHEA and territoriality during the nonbreeding season in male American martens (Martes americana). J. Mammal. 99: 826-835. doi:10.1093/jmammal/gyy067.

Boyd, D.K., and Pletscher, D.H. 1999. Characteristics of dispersal in a colonizing wolf population in the central Rocky Mountains. J. Wildl. Manage. 63: $1093-1108$. doi: $10.2307 / 3802828$.
Bromley, C., and Gese, E.M. 2001a. Surgical sterilization as a method of reducing coyote predation on domestic sheep. J. Wildl. Manage. 65: 510519. doi:10.2307/3803104

Bromley, C., and Gese, E.M. 2001b. Effects of sterilization on territory fidelity and maintenance, pair bonds, and survival rates of free-ranging coyotes. Can. J. Zool. 79(3): 386-392. doi:10.1139/z00-212.

Caughley, G., Pech, R., and Grice, D. 1992. Effect of fertility control on a population's productivity. Wildl. Res. 9: 623-627. doi:10.1071/WR9920623.

Creel, S., and Macdonald, D. 1995. Sociality, group size, and reproductive suppression among carnivores. Adv. Study Behav. 24: 203-257. doi:10.1016/ s0065-3454(08)60395-2.

Creel, S., Creel, N.M., Mills, M.G.L., and Monfort, S.L. 1997. Rank and reproduction in cooperatively breeding African wild dogs: behavioral and endocrine correlates. Behav. Ecol. 8: 298-306. doi:10.1093/beheco/8.3.298.

DeLiberto, T.J., Gese, E.M., Knowlton, F.F., Mason, J.R., Conover, M.R., Miller, L., et al. 1998. Fertility control in coyotes: is it a potential management tool? Vertebr. Pest Conf. 18: 144-149. doi:10.5070/v418110259.

Fuller, T.K., and Snow, W.J. 1988. Estimating winter wolf densities using radiotelemetry data. Wildl. Soc. Bull. 16: 367-370.

Gese, E.M. 1998. Response of neighboring coyotes (Canis latrans) to social disruption in an adjacent pack. Can. J. Zool. 76(10): 1960-1963. doi:10.1139/ z98-128.

Gese, E.M. 2001. Territorial defense by coyotes (Canis latrans) in Yellowstone National Park, Wyoming: who, how, where, when, and why. Can. J. Zool. 79(6): 980-987. doi:10.1139/z01-054.

Gese, E.M., and Mech, L.D. 1991. Dispersal of wolves (Canis lupus) in northeastern Minnesota, 1969-1989. Can. J. Zool. 69(12): 2946-2955. doi:10.1139/ z91-415.

Gese, E.M., and Ruff, R.L. 1997. Scent-marking by coyotes (Canis latrans): the influence of social and ecological factors. Anim. Behav. 54: 1155-1166. doi:10.1006/anbe.1997.0561.

Gese, E.M., and Terletzky, P.A. 2015. Using the "placeholder" concept to reduce genetic introgression of an endangered carnivore. Biol. Conserv. 192: 11-19. doi:10.1016/j.biocon.2015.09.003.

Gese, E.M., Andersen, D.E., and Rongstad, O.J. 1990. Determining homerange size of resident coyotes from point and sequential locations. J. Wildl. Manage. 54: 501-506. doi:10.2307/3809665.

Gese, E.M., Knowlton, F.F., Adams, J.R., Beck, K., Fuller, T.K., Murray, D.L., et al. 2015. Managing hybridization of a recovering endangered species: the red wolf Canis rufus as a case study. Current Zool. 61: 191-205. doi:10.1093/ czoolo/61.1.191.

Hartshorn, G.S. 1972. Vegetation and soil relationships in southern Beaufort County, North Carolina. J. Elisha Mitchell Sci. Soc. 88: 226-237.

Heisey, D.M., and Fuller, T.K. 1985. Evaluation of survival and cause-specific mortality rates using telemetry data. J. Wildl. Manage. 49: 668-674. doi:10.2307| 3801692.

Hinton, J.W., van Manen, F.T., and Chamberlain, M.J. 2015. Space use and habitat selection by resident and transient coyotes (Canis latrans). PLoS ONE, 10(7): e0132203. doi:10.1371/journal.pone.0132203.

Jacob, J., and Matulessy, J. 2004. Effects of imposed sterility on movement patterns of female ricefield rats. J. Wildl. Manage. 68: 1138-1144. doi:10.2193/ 0022-541X(2004)068[1138:EOISOM]2.0.CO;2.

Jolly, S.E., Scobie, S., and Cowan, P.E. 1996. Effects of vaccination against gonadotrophin releasing hormone $(\mathrm{GnRH})$ on the social status of brushtail possums in captivity. N.Z. J. Zool. 23: 325-330. doi:10.1080/03014223.1996. 9518091.

Karlin, M.L., and Chadwick, J. 2012. Red wolf natal dispersal characteristics: comparing periods of population increase and stability. J. Zool. 286: 266276. doi:10.1111/j.1469-7998.2011.00876.x.

Kelly, B.T. 2000. Red wolf recovery program adaptive work plan FY00-FY02. U.S. Fish and Wildlife Service, Atlanta, Ga.

Kennelly, J.J., and Converse, K.A. 1993. Surgical sterilization: an underutilized procedure for evaluating the merits of induced sterility. Contraception in Wildlife Management, Paper 13. USDA Animal and Plant Health Inspection Service, Washington, D.C. Available from https://digitalcommons. unl.edu/nwrccontraception/13/.

Lynch, J.M., and Peacock, S.L. 1982. Natural areas inventory of Hyde County, North Carolina. CEIP Report 28. North Carolina Department of Natural Resources, Raleigh. doi:10.5962/bhl.title.52266.

Massei, G., and Cowan, D. 2014. Fertility control to mitigate human-wildlife conflicts: a review. Wildl. Res. 41: 1-21. doi:10.1071/WR13141.

Mech, L.D., Fritts, S.H., and Nelson, M.E. 1996. Wolf management in the 21st century: from public input to sterilization. J. Wildl. Res. 1: 195-198.

Miller, C.R., Adams, J.R., and Waits, L.P. 2003. Pedigree-based assignment tests for reversing coyote Canis latrans introgression into the wild red wolf Canis rufus population. Mol. Ecol. 12: 3287-3301. doi:10.1046/j.1365294X.2003.02003.X.

Montgomery, T.M., Pendleton, E.L., and Smith, J.E. 2018. Physiological mechanisms mediating patterns of reproductive suppression and alloparental care in cooperatively breeding carnivores. Physiol. Behav. 193: 167-178. doi:10.1016/j.physbeh.2017.11.006.

Moorhead, K.K. 1992. Wetland resources of the coastal North Carolina. Wetlands, 12: 184-191. doi:10.1007/BF03160608. 
Moorhead, K.K., and Brinson, M.M. 1995. Response to wetlands to rising sea level in the lower coastal plain of North Carolina. Ecol. Appl. 5: 261-271. doi:10.2307/1942068.

Neville, P.F., and Remfry, J. 1984. Effect of neutering on two groups of feral cats. Vet. Rec. 114: 447-4540. doi:10.1136/vr.114.18.447. PMID:6730267.

Odum, E.P., and Kuenzler, E.J. 1955. Measurement of territory size in birds. Auk, 72: 128-137. doi:10.2307/4081419.

Phillips, M.K., and Parker, W.T. 1988. Red wolf recovery: a progress report. Conserv. Biol. 2: 139-141. doi:10.1111/j.1523-1739.1988.tb00164.x.

Ramsey, D. 2007. Effects of fertility control on behavior and disease transmission on brushtail possums. J. Wildl. Manage. 71: 109-116. doi:10.2193/ 2005-699.

$\mathrm{R}$ Core Team. 2015. R: a language and environment for statistical computing. R Foundation for Statistical Computing, Vienna, Austria. Available from https://www.r-project.org.

Saunders, G., Mcilroy, J., Berghout, M., Kay, B., Gifford, E., Perry, R., and Van De Ven, R. 2002. The effects of induced sterility on the territorial behavior and survival of foxes. J. Appl. Ecol. 39: 56-66. doi:10.1046/j.13652664.2002.00696.x.

Schwartz, A.M., Baird, T.A., and Timanus, D.K. 2007. Influence of age and prior experience on territorial behavior and the costs of defense in male collared lizards. Ethology, 113: 9-17. doi:10.1111/j.1439-0310.2006.01297.x.

Seidler, R.G., and Gese, E.M. 2012. Territory fidelity, space use, and survival rates of wild coyotes following surgical sterilization. J. Ethol. 30: 345354. doi:10.1007/s10164-012-0330-4.
Seidler, R.G., Gese, E.M., and Conner, M.M. 2014. Using sterilization to change predation rates of wild coyotes: a test case involving pronghorn fawns. Appl. Anim. Behav. Sci. 154: 83-92. doi:10.1016/j.applanim.2014.02.006.

Spence, C.E., Kenyon, J.E., Smith, D.R., Hayes, R.D., and Baer, A.M. 1999. Surgical sterilization of free-ranging wolves. Can. Vet. J. 40(2): 118-121. PMID: 10065320.

Stoskopf, M.K., Beck, K., Fazio, B.B., Fuller, T.K., Gese, E.M., Kelly, B.T., et al. 2005. Implementing recovery of the red wolf - integrating scientists and managers. Wildl. Soc. Bull. 33: 1145-1152. doi:10.2193/0091-7648(2005) 33[1145:FTFIRO]2.0.CO;2.

U.S. Census Bureau. 2010. Beaufort, Dare, Hyde, Tyrrell, and Washington counties, North Carolina. U.S. Census Bureau, Washington, D.C. Available from https://data.census.gov/cedsci/.

U.S. Department of the Interior. 2008. Alligator River National Wildlife Refuge: comprehensive conservation plan. U.S. Fish and Wildlife Service, Southeast Region, Atlanta, Ga.

U.S. Fish and Wildlife Service. 2018. Red wolf species status assessment. U.S. Fish and Wildlife Service, Raleigh, N.C.

Wehi, P.M., Barrell, G.K., and Hickling, G.J. 2006. Hormonal correlates of social rank in an asocial species, the common brushtail possum (Trichosurus vulpecula). Ethology, 112: 639-648. doi:10.1111/j.1439-0310.2005.01185.x.

Worton, B.J. 1989. Kernel methods for estimating the utilization distribution in home-range studies. Ecology, 70: 164-168. doi:10.2307/1938423.

Zar, J. 1996. Biostatistical analysis. 3rd ed. Prentice Hall/Simon and Schuster, Upper Saddle River, N.J. 